\title{
ILLUSTRATIONS
}

Lafayette

frontispiece

Oil by Francesco-Giuseppe Casanova, ca. 1782-1 783. Courtesy of the New-York Historical Society.

Map of the retreat from Barren Hill

Ink and watercolor copy of map by Michel Capitaine du Chesnoy.

Courtesy of the Cornell University Libraries, Sparks Maps.

The French squadron anchored before New York, July 12,

1778

12

Wash drawing by Pierre Ozanne, 1778. Library of Congress, Geography and Map Division.

Marching regulations from the Baron von Steuben's Regulations for the Order and Discipline of the Troops of the United States

(Philadelphia, 1779), pp. $5^{8-59}$. Courtesy of the American Antiquarian Society.

Armand-Charles Tuffin, marquis de La Rouerie (Colonel Armand)

Oil by Charles Willson Peale(?), ca. $1783^{-1} 784$. The Historical Society of Pennsylvania.

Signature page of the Treaty of Alliance between France and the United States, February 6, 1778

American original, signed by Conrad-Alexandre Gérard, Benjamin Franklin, Silas Deane, and Arthur Lee. Courtesy of the National Archives and Records Service.

Lafayette's oath of allegiance to the United States, June 9, 1778 Signed by Lafayette, attested by George Washington; printed form completed in John Laurens's hand. Courtesy of the National Archives and Records Service: RG 93, War Department Collection of Revolutionary War Records, 165:4.

Conrad-Alexandre Gérard

Oil by Charles Willson Peale, 1779. Independence National Historical Park Collection. 
The Comte d'Estaing

Colored mezzotint by P. Frieslheim, date unknown. Courtesy of the Fogg Art Museum, Harvard University, Grenville L. Winthrop Collection.

John Hancock

Oil by John Singleton Copley, 1765 . Courtesy of the Museum of Fine Arts, Boston.

Battle of and retreat from Rhode Island, August 29-30, 1778

Detail of map of Narrangansett Bay and Rhode Island by J. Denison, $1778($ ?). Courtesy of the Massachusetts Historical Society.

Map of the positions occupied by the American troops after their retreat from Rhode Island, August 3o, 1778

Ink and watercolor copy of map by Michel Capitaine du Chesnoy. Courtesy of the Cornell University Libraries, Sparks Maps.

George Washington

Oil by Charles Willson Peale, 1776. Courtesy of the Brooklyn Museum, Dick S. Ramsay Fund.

Frederick Howard, fifth earl of Carlisle Oil by George Romney, 1781. Courtesy of the Ivens Collection, London. Photo courtesy of Sotheby and Company, London.

Congress to Louis XVI, October 21,1778

Signed by Henry Laurens. Courtesy of the Archives du Ministère

des Affaires Etrangères: Correspondance politique, Etats-Unis, vol. 5 , fol. 133 .

Designs of the sword presented by Congress to Lafayette, 1779 Enclosed in Benjamin Franklin to the president of Congress, October 4, 1779 (DNA: RG 36o, PCC 82, 1:149-72). Courtesy of the National Archives and Records Service: RG 36o, PCC 59, $1: 38$.

\section{Memoir of 1779}

Next-to-last pages of the manuscript in Lafayette's hand. Courtesy of the Cornell University Libraries, Dean Collection.

Louis XVI

Oil by Antoine-François Callet, 1775 . Courtesy of the Musée National du Château de Versailles. Photo by the Musées Nationaux, Paris.

Benjamin Franklin

Marble bust by Jean-Antoine Houdon, 1778. The Metropolitan Museum of Art, Gift of John Bard, 1872. 

of the Bibliothèque Nationale, Cabinet des Médailles, Paris.

John Paul Jones

Marble bust by Jean-Antoine Houdon, 1781. Courtesy of the United States Naval Academy Museum.

List of British Cruelties

Ca. May 19, 1779. In handwriting of Franklin and Lafayette.

Library of Congress, Manuscript Division, Franklin Papers.

Arthur Lee

Oil by Charles Willson Peale, 1785 . Independence National Historical Park Collection.

George Washington

Oil by Louis Trinquesse, 1779. Courtesy of the Château de Blois.

Charles Gravier, comte de Vergennes

Oil by unidentified artist, date unknown. Courtesy of the Musée

National du Château de Versailles. Photo by the Musées Nationaux, Paris.

William Temple Franklin

Oil miniature by John Trumbull, 1790. Courtesy of Yale University Art Gallery.

George Washington

Drawn by Charles-Nicolas Cochin, engraved by Augustin de Saint-Aubin, ca. 1779. Courtesy of the Historical Society of Pennsylvania.

George III

Oil by Benjamin West, ca. 1779. The Cleveland Museum of Art, gift of Mr. and Mrs. Lawrence S. Robbins.

Alexandre-Marie-Léonor de Saint-Mauris, prince de Montbarey

Engraving by Pierre-François Laurent, 1779. Courtesy of the Bibliothèque Nationale, Cabinet des Estampes, Paris.

Antoine-Raymond-Jean-Gualbert-Gabriel de Sartine

Oil by unidentified artist, date unknown. Courtesy of the Musée

National du Château de Versailles. Photo by the Musées Nationaux, Paris. 